\title{
3D Printing in COVID-19: Productivity Estimation of the Most Promising Open Source Solutions in Emergency Situations
}

\author{
Mika Salmi ${ }^{1, *(D)}$, Jan Sher Akmal ${ }^{1}\left(\mathbb{D}\right.$, Eujin Pei ${ }^{2}$, Jan Wolff ${ }^{3,4}$, Alireza Jaribion ${ }^{5}$ and \\ Siavash H. Khajavi ${ }^{5}$ \\ 1 Department of Mechanical Engineering, Aalto University, 02150 Espoo, Finland; jan.akmal@aalto.fi \\ 2 Department of Design, Brunel University London, London UB8 3PH, UK; Eujin.Pei@brunel.ac.uk \\ 3 Fraunhofer Research Institution for Additive Manufacturing Technologies IAPT, 21029 Hamburg, Germany; \\ jan.wolff@iapt.fraunhofer.de \\ 4 Division for Regenerative Orofacial Medicine, Department of Oral and Maxillofacial Surgery, \\ University Hospital Hamburg-Eppendorf, 20251 Hamburg, Germany \\ 5 Department of Industrial Engineering and Management, Aalto University, 02150 Espoo, Finland; \\ alireza.jaribion@aalto.fi (A.J.); siavash.khajavi@aalto.fi (S.H.K.) \\ * Correspondence: mika.salmi@aalto.fi
}

Received: 28 April 2020; Accepted: 3 June 2020; Published: 9 June 2020

\begin{abstract}
The COVID-19 pandemic has caused a surge of demand for medical supplies and spare parts, which has put pressure on the manufacturing sector. As a result, 3D printing communities and companies are currently operating to ease the breakdown in the medical supply chain. If no parts are available, 3D printing can potentially be used to produce time-critical parts on demand such as nasal swabs, face shields, respirators, and spares for ventilators. A structured search using online sources and feedback from key experts in the 3D printing area was applied to highlight critical issues and to suggest potential solutions. The prescribed outcomes were estimated in terms of cost and productivity at a small and large scale. This study analyzes the number and costs of parts that can be manufactured with a single machine within $24 \mathrm{~h}$. It extrapolates this potential with the number of identical 3D printers in the world to estimate the global potential that can help practitioners, frontline workers, and those most vulnerable during the pandemic. It also proposes alternative 3D printing processes and materials that can be applicable. This new unregulated supply chain has also opened new questions concerning medical certification and Intellectual property rights (IPR). There is also a pressing need to develop new standards for 3D printing of medical parts for the current pandemic, and to ensure better national resilience.
\end{abstract}

Keywords: coronavirus; additive manufacturing; rapid manufacturing; COVID-19; SARS-CoV-2; 3D printing; supply chain disruption; production; bridge manufacturing; PPE

\section{Introduction}

The COVID-19 pandemic has illustrated the vulnerability of conventional global supply chains. Over the past decade, other major disruptions have also exposed this vulnerability [1,2]. For example, the eruption of an Icelandic volcano in 2010 affected time-critical air shipments [3]. The Japanese earthquake and tsunami in 2011 caused several months of disruption in the automotive industry [4]. Thailand's 2011 floods had a huge impact on the supply chains of computer manufacturers in need of hard disks drives [5]. After Hurricane Harvey in 2017, there was a mass disruption in the U.S. chemical production, which caused shortages of essential industrial building materials [6]. The avian influenza A (H5N1) affected trading and transportation systems in major cities, and caused a destructive effect 
on global food supply and business operation [7]. The coronavirus disease (COVID-19) pandemic has once again demonstrated the fragility of conventional global supply chains. Cost minimization and cost-cutting measures are the most significant drivers that lead to fragility and vulnerability of global supply chains $[7,8]$. To date, a plethora of medical equipment businesses are relying on overseas production in developing countries to minimize costs. This has led to shortages in the supply of much-needed medical and non-medical products required to fight the COVID-19 pandemic. As a result, there is an unprecedented shortage of personal protective equipment (PPE) for healthcare workers, lack of ventilators and spare parts for patients, insufficient supply of sanitizer solutions, and scarcity of coronavirus test kits for the general public. Countries that are affected have imposed bans on the export of PPE and other products critical for health. These bans have subsequently caused a greater disruption of medical supplies, and illustrate the vulnerability of global supplies and logistics amid a large upheaval from the pandemic.

Over the past decade, 3D printing (additive manufacturing) has been increasingly implemented in the medical industry. For example, medical and preoperative models [9], surgical implants [10-13], and tools and templates for operations [14] have been fabricated using 3D printing. Major advantages of 3D printing are its ability to offer mass customization, to produce freeform parts on demand, and to cater to lot size indifference and other patient-specific designs [15-17]. In the current COVID-19 pandemic, 3D printing has been increasingly used to print spare parts for medical devices and protective gear, due to the unavailability of supplies. According to the search volume data of Google, the term "3D printing" was searched 2.2 times more in April 2020 than in the same period last year. Key benefits of 3D printing over conventional manufacturing are faster production, digital storage and traceability of part files, reduction in delivery time, and the ability to produce components regardless of the complexity of part geometry $[18,19]$.

To date, there are only a few publications related to COVID-19 and 3D printing. More specifically, the following six topics have been investigated: open source ventilators [20], connectors for breathing devices [21], sourcing PPE [22], pressure-regulated ventilator splitting spare parts [23], respirators [24], and 3D printed ventilator parts [25]. Thus, there is reason to believe that the productivity of 3D printing with regard to the COVID-19 pandemic is not fully understood. The aim of this paper is to investigate the productivity of the most promising open source 3D printing solutions for the COVID-19 pandemic.

\section{Materials and Methods}

\subsection{Gathering the Most Promising Open Source Solutions}

An overview of 3D printers and resulting products used in the COVID-19 pandemic was undertaken using multiple sources including, but not limited to, local newsletters, national government press releases, social media, 3D printing newsletters, university and company webpages, and other professional networks. Based on the collected data, the authors performed a clustering method and selected the most popular and potential products and devices (Table 1) currently used in the COVID-19 pandemic. The selection process was limited to open source parts.

\subsection{D Printing and Cost Model}

Three ISO/ASTM 3D printing processes, namely vat photopolymerization (VP), material extrusion (ME), and powder bed fusion (PBF), are most commonly used to produce parts in the COVID-19 pandemic. The ME process is the most widespread 3D printing technology to date. The VP process is widely used in the medical field to print biocompatible materials. The PBF process is broadly used for producing functional prototypes, end-use parts, and rapid tooling. Table 2 lists the 3D printing machines and materials that are currently being used, or that can otherwise maintain the functional integrity of the respective products. Further, alternative materials can also be used as stated in Table 2 . 
Table 1. Products currently being manufactured using 3D printing in the COVID-19 pandemic.

\begin{tabular}{|c|c|c|c|}
\hline Description & Users & Pandemic Demand & 3D Model Source \\
\hline $\begin{array}{c}\text { Face mask } \\
\text { (filter is attached separately) }\end{array}$ & $\begin{array}{l}\text { Frontline workers: hospital staff, paramedics, law } \\
\text { enforcement authorities, etc.-individual people }\end{array}$ & $\begin{array}{l}\text { Very high } \\
>10 \text { billion }\end{array}$ & https://amaskforall.com/ \\
\hline Face shield (3D printed holder) & $\begin{array}{c}\text { Frontline workers: hospital staff, paramedics, law } \\
\text { enforcement authorities, etc.- } \\
\text { individual people }\end{array}$ & $\begin{array}{l}\text { Very high } \\
>1 \text { billion }\end{array}$ & $\begin{array}{l}\text { https://www.prusaprinters.org/prints/25857-prusa-face-shield } \\
\text { https://www.3dsystems.com/covid-19-response\#faceShield }\end{array}$ \\
\hline Nasal swab & $\begin{array}{l}\text { Hospital staff, paramedics, law enforcement } \\
\text { authorities, etc.- - every person to be tested }\end{array}$ & $\begin{array}{l}\text { Very high } \\
>100 \text { million }\end{array}$ & $\begin{array}{l}\text { https://usf.app.box.com/s/wxmlj0r66vp8bzei6o7sur1kq1jr8o1i } \\
\text { folder/109236323102 }\end{array}$ \\
\hline Venturi valve & Hospitals-shortage of parts & $\begin{array}{l}\text { Medium } \\
>10 \text { million }\end{array}$ & $\begin{array}{l}\text { https://grabcad.com/library/respirator-free-reanimation- } \\
\text { venturi-s-valve-1/details?folder_id=8017467 }\end{array}$ \\
\hline
\end{tabular}

Table 2. 3D Printing technologies and alternatives.

\begin{tabular}{|c|c|c|c|c|c|}
\hline $\begin{array}{c}\text { ISO/ASTM } \\
\text { Technology Class }\end{array}$ & Equipment \& Material & $\begin{array}{c}\text { Layer } \\
\text { Thickness }\end{array}$ & Notes & Sterilization & Alternatives \\
\hline $\begin{array}{c}\text { VAT } \\
\text { Photopolymerization }\end{array}$ & $\begin{array}{l}\text { Form } 2^{\mathrm{TM}} \& \text { Dental SG. } \\
\text { (Formlabs Inc., USA) }\end{array}$ & $0.1 \mathrm{~mm}$ & $\begin{array}{l}\text { Biocompatible material, needs } \\
\text { post-curing and autoclaving }\end{array}$ & Autoclave & $\begin{array}{l}\text { Vat photopolymerization } \\
\text { technologies with material approved } \\
\text { for medical use }\end{array}$ \\
\hline \multirow[t]{2}{*}{ Material Extrusion } & $\begin{array}{l}\text { uPrint }^{\mathrm{TM}} \text { SE Plus \& ABS } \\
\text { (Stratasys Ltd., Israel) }\end{array}$ & $0.33 \mathrm{~mm}$ & $\begin{array}{l}\text { Material not medically approved, } \\
\text { product might not be airtight }\end{array}$ & \multirow[t]{2}{*}{$\begin{array}{l}\text { Isopropyl } \\
\text { alcohol }\end{array}$} & \multirow{2}{*}{$\begin{array}{c}\text { Other material extrusion equipment } \\
\text { and materials, approved material } \\
\text { would be beneficial }\end{array}$} \\
\hline & $\begin{array}{l}\text { Ultimaker }{ }^{\mathrm{TM}} 2 \text { \& ABS } \\
\text { (Ultimaker BV, Dutch) }\end{array}$ & $0.1 \mathrm{~mm}$ & $\begin{array}{l}\text { Material not medically approved, } \\
\text { product might not be airtight }\end{array}$ & & \\
\hline Powder Bed Fusion & $\begin{array}{c}\text { 3DSystems }^{\mathrm{TM}} \text { ProX SLS } 500 \& \\
\text { DuraFormProX PA (3D Systems } \\
\text { Inc., USA) }\end{array}$ & $0.1 \mathrm{~mm}$ & Biocompatible material & Autoclave & $\begin{array}{l}\text { Powder bed fusion technologies with } \\
\text { approved material for medical use }\end{array}$ \\
\hline
\end{tabular}


The build volume of the respective 3D printing machines is often packed/nested in a manner that aims to fully maximize the number of parts within the build area, while maintaining a high probability of a successful print. Though the productivity may be improved by completely packing/nesting the build volume with different types of products in one batch to increase packing density, particularly in the PBF process, this study focuses on identical products to fully pack the build volume for simplicity.

The pre-processing software of different 3D printing processes have an unidentical array of control settings and build parameters, owing to different materials and fusing mechanisms. In principle, a higher layer thickness than the one used in this study may be selected to manufacture the prescribed parts, which would also decrease the print time per batch. However, parts manufactured with an increased layer thickness can yield relatively lower quality and weaker strength. To this end, this study employs standardized 3D printing parameters for both build and support structures prescribed by the original equipment manufacturer (OEM), to confirm process assurance and repeatability of results. The supports were generated using OEM algorithms for the certified material profiles.

Figure 1 shows the packing arrangements of products in different build volumes that enable a good build solution. For example, the nasal swabs intended to be manufactured through the PBF process were not stacked over each other, because the consecutive addition of such a long and narrow geometry would increase the risk of an unsuccessful end result in the build. This research opts for a more pragmatic approach, in which the main focus is on the 3D printing process itself, and the in-depth analyses for post-processing steps, sterilization, and cost of delivery are largely simplified.

A cost model with five components was used in this research. The 3D printing machine and its maintenance, raw material, labor, overhead, and sterilization are the basic cost components. By employing this model, we estimated the cost of producing and sterilizing four exemplar medical parts, namely face masks, nasal swabs, face shield holders, and Venturi valves, using four 3D printing machines with different raw materials and varying batch sizes. Different batch sizes for an identical 3D printing machine have also been selected, to highlight the effect of batch size on the costs related to the pre- and post-processing. In total, 17 experiments were conducted. The setting of the experiments, the data, and the assumptions used to create the cost models are presented in Tables 3-5. Data regarding the build times and material consumptions for the experiments was extracted from the OEM software of the 3D printing machines, because this was the most accessible means of data. The software were PreForm 2.20.0, GrabCAD 1.40.28.60898, Ultimaker Cura 4.5.0, and 3DSprint 2.13.0 for Form $2^{\mathrm{TM}}$, uPrint $^{\mathrm{TM}}$ SE Plus, Ultimaker ${ }^{\mathrm{TM}}$ 2, and 3DSystems ${ }^{\mathrm{TM}}$ ProX SLS 500, respectively.

The assumptions regarding the cost of procuring the 3D printing machine and the estimated annual maintenance are presented in Table 4 . Moreover, the hourly labor cost for the pre- and post-processing of the print job was assumed to be $15 €$ at a minimum hourly wage, and the duration of labor requirement for each print job was estimated through expert opinion. The cost and method of sterilization was extracted from the literature for the 17 experiments, as shown in Table 5. Parts produced from Dental SG and Polyamide 12 can be sterilized by an autoclave, while the ABS parts require submersion in a $\mathrm{C} 3 \mathrm{H} 8 \mathrm{O}[26]$ solution. 
Table 3. Experiment settings and model parameters.

\begin{tabular}{|c|c|c|c|c|c|c|}
\hline Exp. ID & Product & Equipment & Material & $\begin{array}{c}\text { Capacity of Machine } \\
\text { Chamber (L) }\end{array}$ & $\begin{array}{c}\text { Experiment Batch } \\
\text { Size }\end{array}$ & $\begin{array}{c}\text { Print } \\
\text { Time/Batch (h) }\end{array}$ \\
\hline 1 & \multirow{2}{*}{ Nasal swab } & Formlabs Form 2 & Dental SG & 2.58 & 400 & 12.27 \\
\hline 2 & & 3DSystems ProX SLS 500 & PA12 & 57.46 & 3254 & 37.98 \\
\hline 3 & \multirow{5}{*}{ Venturi valve } & Formlabs Form 2 & Dental SG & 2.58 & 18 & 8.03 \\
\hline 4 & & 3DSystems ProX SLS 500 & PA12 & 57.46 & 625 & 54.70 \\
\hline 5 & & \multirow{2}{*}{ Ultimaker 2} & \multirow{3}{*}{ ABS } & 10.19 & 1 & 2.27 \\
\hline 6 & & & & 10.19 & 47 & 108.45 \\
\hline 7 & & uPrint SE Plus & & 6.26 & 24 & 33.75 \\
\hline 8 & \multirow{5}{*}{ Face mask + lid } & Formlabs Form 2 & Dental SG & 2.58 & 1 & 3.92 \\
\hline 9 & & 3DSystems ProX SLS 500 & PA12 & 57.46 & 120 & 36.65 \\
\hline 10 & & \multirow{2}{*}{ Ultimaker 2} & \multirow{3}{*}{ ABS } & 10.19 & 2 & 19.62 \\
\hline 11 & & & & 10.19 & 18 & 195.65 \\
\hline 12 & & uPrint SE Plus & & 6.26 & 2 & 12.27 \\
\hline 13 & \multirow{4}{*}{ Face shield holder } & 3DSystems ProX SLS 500 & PA12 & 57.46 & 88 & 38.00 \\
\hline 14 & & \multirow{2}{*}{ Ultimaker 2} & \multirow{3}{*}{ ABS } & 10.19 & 1 & 6.85 \\
\hline 15 & & & & 10.19 & 10 & 76.35 \\
\hline 16 & & uPrint SE Plus & & 6.26 & 1 & 3.48 \\
\hline 17 & $\begin{array}{l}\text { Face shield holder } \\
\text { SLS optimized }\end{array}$ & 3DSystems ProX SLS 500 & PA12 & 57.46 & 374 & 102.52 \\
\hline
\end{tabular}


Table 4. Cost model estimates.

\begin{tabular}{|c|c|c|c|c|c|c|c|c|}
\hline $\begin{array}{l}\text { Exp. } \\
\text { ID }\end{array}$ & $\begin{array}{l}\text { Material } \\
\text { per Build }\end{array}$ & $\begin{array}{l}\text { Support Material } \\
\text { Volume }\end{array}$ & $\begin{array}{l}\text { Material } \\
\text { Cost }\end{array}$ & $\begin{array}{l}\text { Cost of 3D } \\
\text { Printer }(k €)\end{array}$ & $\begin{array}{l}\text { Expected Lifespan of } \\
\text { 3D Printer (years) }\end{array}$ & $\begin{array}{l}\text { 3D Printer Maintenance } \\
\text { (Annual Cost in k€) }\end{array}$ & $\begin{array}{c}\text { Labor Cost } \\
\text { per Hour }(€)\end{array}$ & $\begin{array}{l}\text { Labor Required per 3D Printer } \\
\text { (Person Hour per Run) }\end{array}$ \\
\hline 1 & $224 \mathrm{ml}$ & \multirow{2}{*}{ Not needed } & $270 € / 1$ & 2.7 & 3 & 0.5 & \multirow{17}{*}{15} & 2 \\
\hline 2 & 40.061 & & $13.5 € / 1$ & 350 & 10 & 10 & & 8 \\
\hline 3 & $167 \mathrm{ml}$ & Included in the build & $270 € / 1$ & 2.7 & 3 & 0.5 & & 2 \\
\hline 4 & 49.641 & Not needed & $13.5 € / 1$ & 350 & 10 & 10 & & 5 \\
\hline 5 & $9 \mathrm{~g}$ & $1 \mathrm{~g}$ & \multirow{2}{*}{$0.06 € / g$} & 1.9 & 2 & 0.4 & & 0.5 \\
\hline 6 & $412 \mathrm{~g}$ & $44 \mathrm{~g}$ & & 1.9 & 2 & 0.4 & & 2 \\
\hline 7 & $197 \mathrm{~cm}^{3}$ & $107 \mathrm{~cm}^{3}$ & $0.29 € / \mathrm{cm}^{3}$ & 16 & 8 & 1 & & 1 \\
\hline 8 & $70 \mathrm{ml}$ & Included in the build & $270 € / 1$ & 2.7 & 3 & 0.5 & & 1.5 \\
\hline 9 & 54.231 & Not needed & $13.5 € / 1$ & 350 & 10 & 10 & & 4 \\
\hline 10 & $90 \mathrm{~g}$ & $8 \mathrm{~g}$ & \multirow{2}{*}{$0.06 € / g$} & 1.9 & 2 & 0.4 & & 0.5 \\
\hline 11 & $780 \mathrm{~g}$ & $185 \mathrm{~g}$ & & 1.9 & 2 & 0.4 & & 1.5 \\
\hline 12 & $136 \mathrm{~cm}^{3}$ & $35 \mathrm{~cm}^{3}$ & $0.29 € / \mathrm{cm}^{3}$ & 16 & 8 & 1 & & 0.5 \\
\hline 13 & 54.181 & Not needed & $13.5 € / 1$ & 350 & 10 & 10 & & 4 \\
\hline 14 & $33 \mathrm{~g}$ & $1 \mathrm{~g}$ & \multirow{2}{*}{$0.06 € / g$} & 1.9 & 2 & 0.4 & & 0.5 \\
\hline 15 & $312 \mathrm{~g}$ & $32 \mathrm{~g}$ & & 1.9 & 2 & 0.4 & & 1 \\
\hline 16 & $37 \mathrm{~cm}^{3}$ & $10 \mathrm{~cm}^{3}$ & $0.29 € / \mathrm{cm}^{3}$ & 16 & 8 & 1 & & 0.5 \\
\hline 17 & 54.391 & Not needed & $13.5 € / 1$ & 350 & 10 & 10 & & 4 \\
\hline
\end{tabular}


Table 5. Sterilization cost model estimates.

\begin{tabular}{|c|c|c|c|c|c|c|c|}
\hline $\begin{array}{l}\text { Exp. } \\
\text { ID }\end{array}$ & $\begin{array}{l}\text { Sterilization } \\
\text { Method }\end{array}$ & $\begin{array}{c}\text { Sterilization Equipment } \\
\text { Cost of a 60L Benchtop } \\
\text { Autoclave (k€) }\end{array}$ & $\begin{array}{c}\text { Cost of Sterilization } \\
\text { Material } 70 \%(€ / L)\end{array}$ & $\begin{array}{c}\text { Amount of } \\
\text { Alcohol Needed } \\
\text { for a Batch (L) }\end{array}$ & $\begin{array}{c}\text { Sterilization } \\
\text { Equipment Annual } \\
\text { Maintenance Cost }(\mathbf{k})\end{array}$ & $\begin{array}{c}\text { Length of } \\
\text { Autoclave Process } \\
\text { (h) }\end{array}$ & $\begin{array}{c}\text { Hourly } \\
\text { Sterilization Cost } \\
(€)\end{array}$ \\
\hline 1 & \multirow{4}{*}{ Autoclave } & \multirow{4}{*}{15} & \multirow{4}{*}{-} & \multirow{4}{*}{-} & \multirow{4}{*}{1} & 1.0 & \multirow{4}{*}{1.04} \\
\hline 2 & & & & & & 0.5 & \\
\hline 3 & & & & & & 1.0 & \\
\hline 4 & & & & & & 0.5 & \\
\hline 5 & \multirow{3}{*}{ С $3 \mathrm{H} 8 \mathrm{O}$} & \multirow{3}{*}{-} & \multirow{3}{*}{9} & 0.5 & \multirow{3}{*}{-} & \multirow{3}{*}{-} & \multirow{3}{*}{-} \\
\hline 6 & & & & 5.0 & & & \\
\hline 7 & & & & 0.5 & & & \\
\hline 8 & \multirow{2}{*}{ Autoclave } & \multirow{2}{*}{15} & \multirow{2}{*}{-} & \multirow{2}{*}{ - } & \multirow{2}{*}{1} & 1.0 & \multirow{2}{*}{1.04} \\
\hline 9 & & & & & & 0.5 & \\
\hline 10 & \multirow{3}{*}{ С3H8O } & \multirow{3}{*}{ - } & \multirow{3}{*}{9} & 1.0 & \multirow{3}{*}{-} & \multirow{3}{*}{-} & \multirow{3}{*}{-} \\
\hline 11 & & & & 5.0 & & & \\
\hline 12 & & & & 0.5 & & & \\
\hline 13 & Autoclave & 15 & - & - & 1 & 0.5 & 1.04 \\
\hline 14 & \multirow{2}{*}{ С3H8O } & \multirow{2}{*}{-} & \multirow{2}{*}{9} & 1.0 & \multirow[t]{2}{*}{-} & \multirow[t]{2}{*}{-} & \multirow[t]{2}{*}{-} \\
\hline 15 & & & & 5.0 & & & \\
\hline 16 & $\mathrm{C} 3 \mathrm{H} 8 \mathrm{O}$ & - & 9 & 1.0 & - & - & - \\
\hline 17 & Autoclave & 15 & - & - & 1 & 0.5 & 1.04 \\
\hline
\end{tabular}



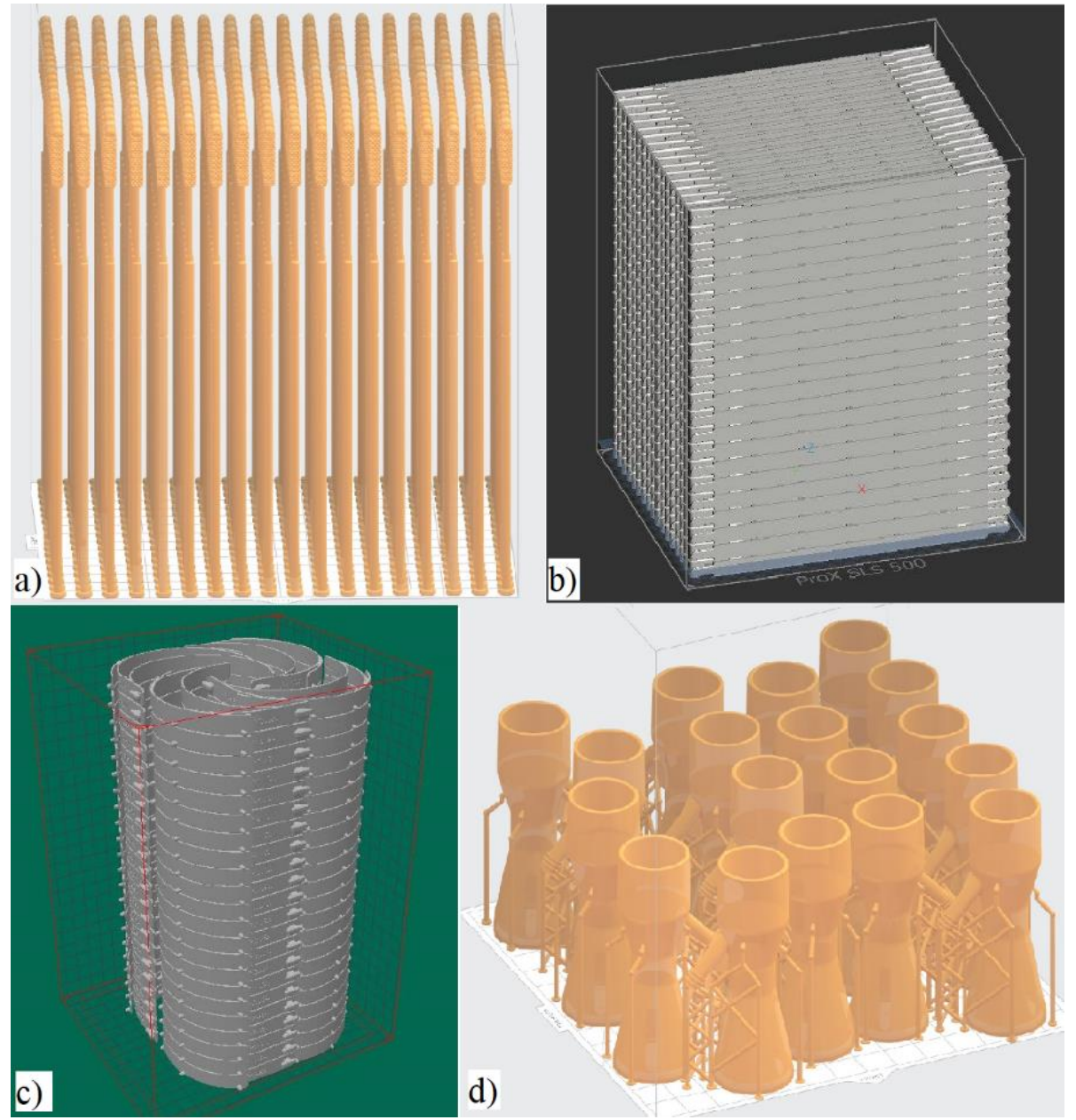

Figure 1. Packing solutions of parts in different build volumes: (a) nasal swab in Form 2; (b) face shield holder SLS optimized in ProX SLS 500; (c) face shield holder in ProX SLS 500; and (d) Venturi valve in Form 2.

\section{Results}

Products currently being manufactured using 3D printing in the COVID-19 pandemic are generally face masks, face shields, nasal swabs, and Venturi valves (Table 1). The estimated cost and productivity of different products with different 3D printing technologies, when extrapolated over the estimated amount of identical equipment in the market, are shown in Table 6. The results indicate the potential number of products that can be manufactured with one set of equipment, and with all the equipment available in the market. Table 7 lists the overall estimated costs. The most potential ones are those that have a high productivity with a single set of equipment and widespread availability of equipment in the market.

However, there are similar 3D printers from different manufacturers in the market that can be used to manufacture these products and devices using comparable materials. Thus, the total 3D printing potential in the world is in fact conservatively estimated to be at least 10-100 times larger, and therefore can have a huge impact on the lack of medical supply in the current situation. Furthermore, it should be noted that certain 3D printing technologies are better for manufacturing specific types of products than others. To this end, there is a need to deploy an optimal 3D printing technology for each application to maximize the production of required parts. 
Table 6. The potential productivity of using 3D printing.

\begin{tabular}{|c|c|c|c|c|c|c|}
\hline Exp. ID & Description & Equipment & Batch Size & $\begin{array}{c}\text { Productivity } \\
\text { Units/24h }\end{array}$ & $\begin{array}{c}\text { Estimated No. of } \\
\text { Equipment in the World }\end{array}$ & $\begin{array}{l}\text { Total Potential } \\
\text { Units/24h }\end{array}$ \\
\hline 1 & Nasal swab & Formlabs Form 2 & 400 & 783 & $50 \mathrm{k}$ & 39130k \\
\hline 2 & Nasal swab & 3DSystems ProX SLS 500 & 3254 & 2056 & $1 \mathrm{k}$ & $2056 \mathrm{k}$ \\
\hline 3 & Venturi valve & Formlabs Form 2 & 18 & 54 & $50 \mathrm{k}$ & $2688 \mathrm{k}$ \\
\hline 4 & Venturi valve & 3DSystems ProX SLS 500 & 625 & 274 & $1 \mathrm{k}$ & $274 \mathrm{k}$ \\
\hline 5 & Venturi valve & Ultimaker 2 & 1 & 11 & $100 \mathrm{k}$ & $1058 \mathrm{k}$ \\
\hline 6 & Venturi valve & Ultimaker 2 & 47 & 10 & $100 \mathrm{k}$ & 1040k \\
\hline 7 & Venturi valve & uPrint SE Plus & 24 & 17 & $5 \mathrm{k}$ & $85 \mathrm{k}$ \\
\hline 8 & Face mask + lid & Formlabs Form 2 & 1 & 6,1 & $50 \mathrm{k}$ & $306 \mathrm{k}$ \\
\hline 9 & Face mask + lid & 3DSystems ProX SLS 500 & 120 & 79 & $1 \mathrm{k}$ & $78 \mathrm{k}$ \\
\hline 10 & Face mask + lid & Ultimaker 2 & 2 & 2,4 & $100 \mathrm{k}$ & $244 \mathrm{k}$ \\
\hline 11 & Face mask + lid & Ultimaker 2 & 18 & 2,2 & $100 \mathrm{k}$ & $220 \mathrm{k}$ \\
\hline 12 & Face mask + lid & uPrint SE Plus & 2 & 3,9 & $5 \mathrm{k}$ & $19 \mathrm{k}$ \\
\hline 13 & Face shield holder & 3DSystems ProX SLS 500 & 88 & 56 & $1 \mathrm{k}$ & $55 \mathrm{k}$ \\
\hline 14 & Face shield holder & Ultimaker 2 & 1 & 3,5 & $100 \mathrm{k}$ & $350 \mathrm{k}$ \\
\hline 15 & Face shield holder & Ultimaker 2 & 10 & 3,1 & $100 \mathrm{k}$ & $314 \mathrm{k}$ \\
\hline 16 & Face shield holder & uPrint SE Plus & 1 & 6,9 & $5 \mathrm{k}$ & $34 \mathrm{k}$ \\
\hline 17 & $\begin{array}{l}\text { Face shield holder } \\
\text { (SLS optimized) }\end{array}$ & 3DSystems ProX SLS 500 & 374 & 88 & $5 \mathrm{k}$ & $437 \mathrm{k}$ \\
\hline
\end{tabular}


Table 7. The cost analysis of medical parts.

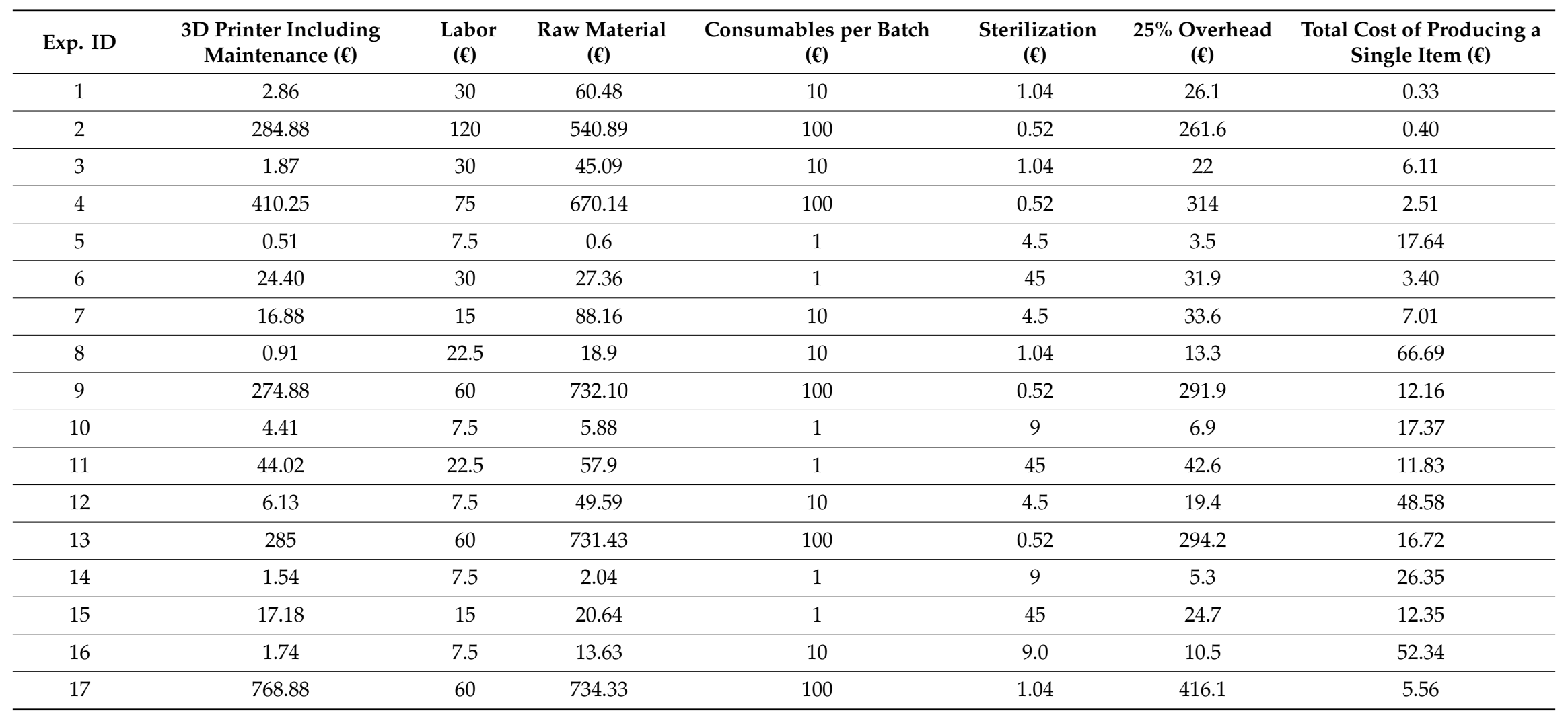


The total cost for each 3D printed batch is calculated by the summation of machine acquisition and maintenance costs, labor, raw materials, consumable items, sterilization, and a $25 \%$ overhead cost. To estimate the individual cost per part, the total cost of 3D printing the batch is divided by the size of the production batch. For instance, the cost of producing a batch of 400 nasal swabs using the Formlabs Form 2 machine is about $130.5 €$, which translates to $0.33 €$ for a single nasal swab. Similarly, the cost of producing the same part on a ProX SLS 500, which is a larger industrial PBF machine, is $0.40 €$, as shown in Table 7. The total cost of producing a single item with different cost components is shown in Figure 2. Two different batch sizes, used for the production of identical parts, in Ultimaker 2 confirm that a percentage increase in costs is significantly lower than the percentage increase in batch size. This is because certain pre- and post- processes, i.e., labor, sterilization, and overhead, which can be seen as dominating factors for small batches in Figure 2, are inevitable, and possess higher throughput capacity than just one or two parts.

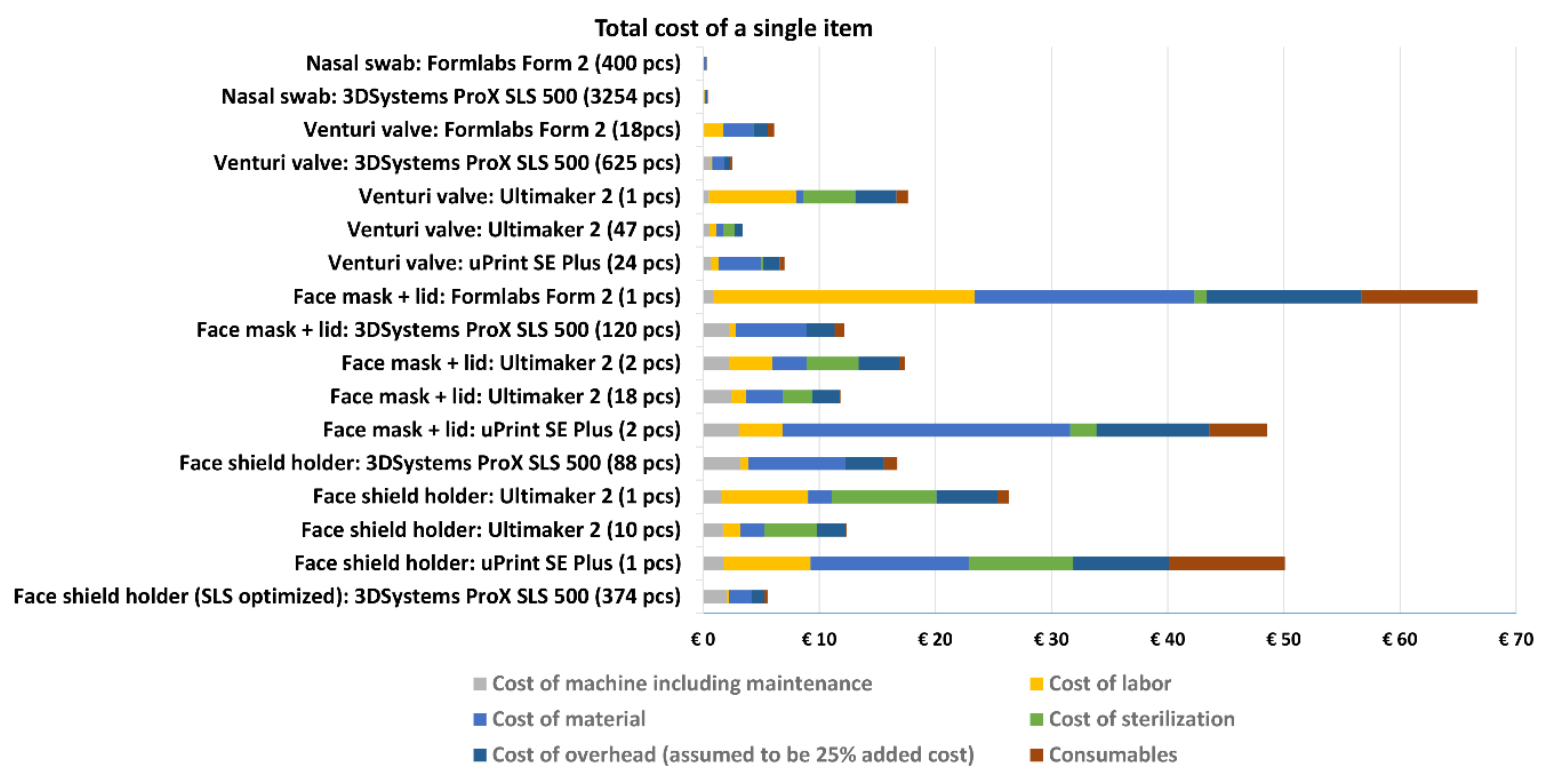

Figure 2. Total cost of producing a single item as a function of different 3D printers, batch sizes (shown in parentheses), and cost components.

\section{Discussion}

This study discusses the potential of using 3D printing (additive manufacturing) to manufacture products required during the COVID-19 pandemic in the year 2020. Examples of products include face shields, respirators, nasal swabs, and ventilator parts. Face shields and respirators pose an interesting challenge for manufacturers, to ensure that they are fabricated within the shortest time frame in which the efficiency of the design and shortest build time is paramount. However, they need an assembly phase, such as adding a transparent plastic shield or a filter. Parts for ventilators and nasal swabs pose a more technical challenge for manufacturers in light of intellectual patent laws. All the products are still required to have compliance with healthcare standards and regulations.

At the moment, some countries suffering from the pandemic have accelerated the approval process for using 3D printing to produce supplies for hospitals. Countries currently facing critical shortage of supplies have even had to bypass some stringent regulations and approval stages with the acceptance of run-of-the-mill solutions. One problematic factor is also the availability of 3D models for certain parts. Companies aim to protect their designs and their intellectual property (IP), but at the same time suffer from their limited manufacturing capacity. 3D printing may allow for an increase in the availability of manufacturing capacity to react quickly, but their unwillingness to share the designs will remain the greatest challenge. Nevertheless, open source community platforms, designers, makers, artists, and even some companies have started to embrace this movement to share their designs and have made 
collaborative development possible. This chain reaction has sped up the solutions remarkably because people are able to incrementally innovate over each other, and there is a possibility to learn from what others have done. This has been one of the biggest reasons why 3D printing applications related to COVID-19 have been developed so rapidly.

Previous work has acknowledged that 3D printing can be used to support the spare parts market $[27,28]$. However, it must be noted that patent laws regarding such 3D printed spare parts will need to be further resolved in the future. The COVID-19 pandemic has increased the pressure on manufacturers to make their designs freely available, particularly in cases where spares may not be readily accessible due to disruption in production plants, logistics, and supply chains. Current spare parts are stored as physical inventory for which logistic networks or deliveries may not be functional. Lastly, if tooling is required to re-initiate production, this can contribute to increasing costs for companies and end-users. Another area of contention is that "repairing patent-protected products with digital spare parts could risk infringing upon the intellectual property rights (IPR) of patent holders" [27]. For example, to repair a protected device using a spare part, part of the invention may be reproduced, and thereby infringement can occur. Fortunately in most European jurisdictions, infringement only occurs if repair activities are undertaken for commercial purposes, and private use is therefore exempted [29]. The concept of "repair" is still interpreted differently in different EU member states, in terms of legitimate repair or when repair counts as infringing upon the rights of the patentee. There has been no agreement on the interpretation of "repair" in the EU, and further clarity is needed as to what extent producing, transforming, assembling, or constructing a product is considered to be "legitimate".

To support the efforts towards the fight against COVID-19, the National Institutes of Health (NIH) [30] in the U.S. has made the computer-aided design (CAD) models of PPE products freely available on its website, and has also divided them into two categories. Non-critical products include air exchangers, filter adaptors, in-line filter housing, and pneumotachometers. Products that have safety implications include ventilator splitters, Venturi valves, and flow restriction devices that pose a much greater risk if used or produced incorrectly. This digital library was created to support the manufacturing of PPE and other medical devices in short supply due to the COVID-19 outbreak. The NIH, Food and Drug Administration (FDA), Veterans Affairs (VA), America Makes, and contributors acknowledged that they cannot ensure the quality, safety, and efficacy of these designs when manufactured without proper quality controls and processes. As a result, ASTM International [30] has enabled public access to relevant ASTM standards used in the production and testing of PPE such as for face masks, medical gowns, gloves, and hand sanitizers. Other efforts, such as the U.K. Government Office for Product Safety and Standards, have also published guidelines to assist manufacturing companies planning to convert their operations to produce PPE. These include ways to have products approved for sale or to be donated to the government to be used by healthcare workers. It also provides guidance on what manufacturers have to do to fulfil those obligations, and contacts to U.K. Notified Bodies that can assess PPE for COVID-19 [31]. However, it must be noted that at the time of writing, there are still no specific standards available when using 3D printing for the production of PPE to ensure total compliance with healthcare protocols.

In terms of the digital value chain when designing and producing parts for 3D printing, the ISO document, "ISO 17296-4:2016 Additive manufacturing - General principles - Overview of data processing" [32], suggests that data exchange methods could include the file type, data enclosed formatting of such data, and what this can be used for. Examples of suitable formats for data exchange include .STL, .STEP, and .AMF. Of these, the .STL file is still the most commonly used format, and this has been observed in the file formats available in the digital library for COVID-19 CAD files. One of the drawbacks is that .STL files do not specify units. Newer file formats have been made available, such as the .AMF file format that can contain metadata such as information of the CAD source, design and production specifications, supplier information, and production data. The .AMF file format is also able to support constellations that describe the build pack, stacking, nesting, or orientation of parts. 
The .AMF file format is also XML-based, and users with a text editor are able to quickly open, view, and edit the metadata content. Other useful formats that could provide a more accurate and efficient manufacturing workflow include the .3MF file format.

$3 \mathrm{D}$ printing in a bridge manufacturing mode has tremendously supported the fight against the COVID-19 pandemic [33]. Local or distributed manufacturing [34,35], supply chain modifications, and enhanced education can help us achieve a more stable supply chain, as well as mitigate a number of shortcomings $[28,36,37]$. The labor requirements for pre- and post-production steps of 3D printing, in addition to the throughput of the 3D printer, limited range of raw materials, and multi-material process constraints, call for further technological advancements to improve the competitiveness of 3D printing, and to deal with raw material shortages [38].

This study was limited to open source parts because they are accessible to everyone, and therefore have the biggest impact. The work used few exemplar parts to highlight the potential of 3D printing, however there is a wide range of similar open source parts made available in open access repositories. Future studies are recommended to focus on the technical verification of the parts. Cost and productivity models are estimations, and are simplified to provide valuable insights about the cost structure and productivity that 3D printing is capable of achieving in the COVID-19 pandemic.

\section{Conclusions}

To fully capitalize on the use of 3D printing during the COVID-19 pandemic for the production of parts in a state of emergency requires a technical know-how and understanding of technologies and materials that will conform to the quality and functional integrity of the intended products. In the ongoing viral outbreak, there is a very high demand for PPE, swabs, and spare parts, due to the breakdown of global supply chains. On the basis of the findings, our analysis provides statistical evidence that the most potential healthcare products that can be manufactured using $3 \mathrm{D}$ printing are those that have a high productivity with a single set of equipment and with widespread availability of equipment in the market. However, this new unregulated supply chain has also opened new questions concerning product certification and IP. There is a pressing need to develop 3D printing medical standards for current and future pandemics.

Author Contributions: Conceptualization: M.S. and J.W.; methodology: M.S., J.S.A., and S.H.K.; software: M.S., J.S.A., and S.H.K.; validation: A.J., E.P., and J.W.; resources and data curation: M.S., J.S.A., S.H.K., A.J., E.P., and J.W.; writing — original draft preparation: M.S., J.S.A., S.H.K., A.J., E.P., and J.W.; writing-review and editing: M.S., J.S.A., S.H.K., A.J., E.P., and J.W.; visualization: M.S.; supervision: M.S.; project administration: M.S.; funding acquisition: M.S. All authors have read and agreed to the published version of the manuscript.

Funding: This research was funded by Academy of Finland, grant number 325509, in the frame of project Direct digital manufacturing in health care production and operations (DiDiMinH).

Conflicts of Interest: The authors declare no conflicts of interest.

\section{References}

1. Chopra, S.; Sodhi, M. Reducing the risk of supply chain disruptions. MIT Sloan Manag. Rev. 2014, 55, 72-80.

2. Choi, T.Y.; Rogers, D.; Vakil, B. Coronavirus is a wake-up call for supply chain management. Harv. Bus. Rev. 2020.

3. Budd, L.; Griggs, S.; Howarth, D.; Ison, S. A fiasco of volcanic proportions? Eyjafjallajökull and the closure of European airspace. Mobilities 2011, 6, 31-40. [CrossRef]

4. Canis, B. Motor Vehicle Supply Chain: Effects of the Japanese Earthquake and Tsunami; Congressional Research Service Publishing: Washington, DC, USA, 2011; pp. 1-16.

5. Chongvilaivan, A. Thailand's 2011 flooding: Its impact on direct exports and global supply chains. ARTNeT Policy Brief 2012, 113, 1-34.

6. Shaheen, I.; Azadegan, A.; Lucianetti, L.; Qi, L. Leading organizations through supply chain disruptions: An exploratory study of necessary traits. Rutgers Bus. Rev. 2017, 2, 322-337. 
7. Kumar, S.; Chandra, C. Supply chain disruption by avian flu pandemic for US companies: A case study. Transp. J. 2010, 49, 61-73.

8. Hoffman, W. Preparing for pandemic. Traffic World 2006, 270, 10-12.

9. Mäkitie, A.; Paloheimo, K.S.; Björkstrand, R.; Salmi, M.; Kontio, R.; Salo, J.; Yan, Y.; Paloheimo, M.; Tuomi, J. Medical applications of rapid prototyping-three-dimensional bodies for planning and implementation of treatment and for tissue replacement. Duodecim 2010, 126, 143-151.

10. Pettersson, A.; Salmi, M.; Vallittu, P.; Serlo, W.; Tuomi, J.; Mäkitie, A.A. Main clinical use of additive manufacturing (three-dimensional printing) in Finland restricted to the head and neck area in 2016-2017. Scand. J. Surg. 2020, 109, 166-173. [CrossRef]

11. Salmi, M.; Tuomi, J.; Paloheimo, K.; Paloheimo, M.; Björkstrand, R.; Mäkitie, A.A.; Mesimäki, K.; Kontio, R. Innovative Developments in Design and Manufacturing; CRC Press: Boca Raton, FL, USA, 2009; pp. 357-360.

12. Akmal, J.S.; Salmi, M.; Mäkitie, A.; Björkstrand, R.; Partanen, J. Implementation of industrial additive manufacturing: Intelligent implants and drug delivery systems. J. Funct. Biomater. 2018, 9, 41. [CrossRef]

13. Akmal, J.S.; Salmi, M.; Hemming, B.; Linus, T.; Suomalainen, A.; Kortesniemi, M.; Partanen, J.; Lassila, A. Cumulative inaccuracies in implementation of additive manufacturing through medical imaging, 3D thresholding, and 3D modeling: A case study for an end-use implant. Appl. Sci. 2020, 10, 2968. [CrossRef]

14. Huotilainen, E.; Salmi, M.; Lindahl, J. Three-dimensional printed surgical templates for fresh cadaveric osteochondral allograft surgery with dimension verification by multivariate computed tomography analysis. Knee 2019, 26, 923-932. [CrossRef] [PubMed]

15. Salmi, M.; Tuomi, J.; Sirkkanen, R.; Ingman, T.; Makitie, A. Rapid tooling method for soft customized removable oral appliances. Open Dent. J. 2012, 6, 85-89. [CrossRef] [PubMed]

16. Zadpoor, A.A. Design for additive bio-manufacturing: From patient-specific medical devices to rationally designed meta-biomaterials. Int. J. Mol. Sci. 2017, 18, 1607. [CrossRef]

17. Thompson, M.K.; Moroni, G.; Vaneker, T.; Fadel, G.; Campbell, R.I.; Gibson, I.; Bernard, A.; Schulz, J.; Graf, P.; Ahuja, B. Design for additive manufacturing: Trends, opportunities, considerations, and constraints. Cirp Ann. 2016, 65, 737-760. [CrossRef]

18. Kretzschmar, N.; Chekurov, S.; Salmi, M.; Tuomi, J. Evaluating the readiness level of additively manufactured digital spare parts: An industrial perspective. Appl. Sci. 2018, 8, 1837. [CrossRef]

19. Chekurov, S.; Metsä-Kortelainen, S.; Salmi, M.; Roda, I.; Jussila, A. The perceived value of additively manufactured digital spare parts in industry: An empirical investigation. Int. J. Prod. Econ. 2018, 205, 87-97. [CrossRef]

20. Pearce, J.M. A review of open source ventilators for COVID-19 and future pandemics. F1000Research 2020, 9 , 218. [CrossRef]

21. Cavallo, L.; Marcianò, A.; Cicciù, M.; Oteri, G. 3D printing beyond dentistry during COVID 19 epidemic: A technical note for producing connectors to breathing devices. Prosthesis 2020, 2, 46-52. [CrossRef]

22. Livingston, E.; Desai, A.; Berkwits, M. Sourcing personal protective equipment during the COVID-19 pandemic. JAMA 2020, 323, 1912-1914. [CrossRef]

23. Raredon, M.S.B.; Fisher, C.; Heerdt, P.; Deshpande, R.; Nivison, S.; Fajardo, E.; Akhtar, S.; Raredon, T.; Niklason, L.E. Pressure-Regulated Ventilator Splitting (PReVentS): A COVID-19 response paradigm from yale university. medRxiv 2020. [CrossRef]

24. Provenzano, D.; Rao, Y.J.; Mitic, K.; Obaid, S.N.; Pierce, D.; Huckenpahler, J.; Berger, J.; Goyal, S.; Loew, M.H. Rapid prototyping of reusable 3D-printed N95 equivalent respirators at the George Washington University. Preprint 2020. [CrossRef]

25. Smith, K. 3D printed ventilator parts save lives. Green Left Wkly. 2020, 1257, 19.

26. Industrial Specialties Mfg. \& IS MED Specialties. Plastics Sterilization Compatibility. Available online: https://www.industrialspec.com/resources/plastics-sterilization-compatibility?utm_source=plassterilize\&utm_medium =pdf (accessed on 24 April 2020).

27. Ballardini, R.M.; Ituarte, I.F.; Pei, E. Printing spare parts through additive manufacturing: Legal and digital business challenges. J. Manuf. Technol. Manag. 2018, 29, 958-982. [CrossRef]

28. Khajavi, S.H.; Salmi, M.; Holmström, J. Managing 3D Printing; Springer: Berlin/Heidelberg, Germany, 2020; pp. $45-60$. 
29. Ballardini, R.; Lee, N.R. The Private and Non-commercial Use Defence Revisited. In 3D Printing, Intellectual Property and Innovation: Insights from Law and Technology; Ballardini, R.M., Norrgård, M., Partanen, J., Eds.; Kluwer Law International: Alphen aan den Rijn, The Netherlands, 2017.

30. NIH COVID-19 Supply Chain Response. Available online: https://3dprint.nih.gov/collections/covid-19response (accessed on 13 April 2020).

31. UK Government Office for Product Safety and Standards. New High-Volume Manufacturers of COVID-19 Personal Protective Equipment (PPE) Guidance for Businesses, Version 2. Available online: https://lnkd.in/ dTde5sw (accessed on 14 April 2020).

32. ISO 17296-4:2014. Additive Manufacturing — General Principles - Part 4: Overview of Data Processing; International Organization for Standardization: Geneva, Switzerland, 2016.

33. Khajavi, S.H.; Jaribion, A.; Ehteshami, M. Is 3D Printing a Magic Bullet for Supply Chain at the Time of COVID-19 Pandemic? Rapid News Publications Ltd.: Chester, UK, 2020.

34. Khajavi, S.H.; Partanen, J.; Holmström, J. Additive manufacturing in the spare parts supply chain. Comput. Ind. 2014, 65, 50-63. [CrossRef]

35. Khajavi, S.H.; Holmström, J.; Partanen, J. Additive manufacturing in the spare parts supply chain: Hub configuration and technology maturity. Rapid Prototyp. J. 2018, 24, 1178-1192. [CrossRef]

36. Holweg, M. The limits of 3-D printing. Harv. Bus. Rev. 2015.

37. Oropallo, W.; Piegl, L.A. Ten challenges in 3D printing. Eng. Comput. 2016, 32, 135-148. [CrossRef]

38. Khajavi, S.H.; Deng, G.; Holmström, J.; Puukko, P.; Partanen, J. Selective laser melting raw material commoditization: Impact on comparative competitiveness of additive manufacturing. Int. J. Prod. Res. 2018, 56, 4874-4896. [CrossRef]

(C) 2020 by the authors. Licensee MDPI, Basel, Switzerland. This article is an open access article distributed under the terms and conditions of the Creative Commons Attribution (CC BY) license (http://creativecommons.org/licenses/by/4.0/). 